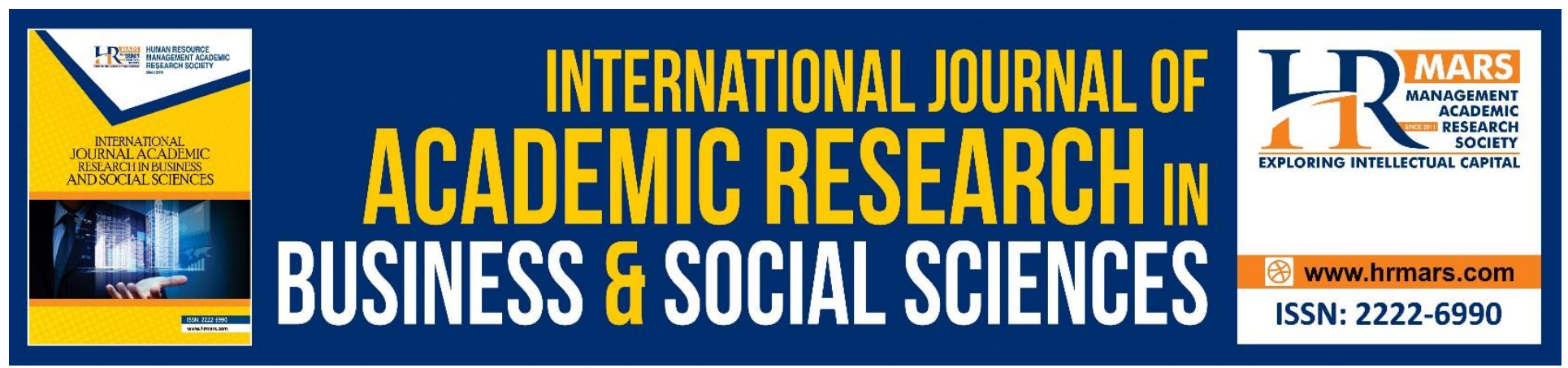

\title{
Non-Ethical Elements in Tawarruq Munazzam Product for Islamic Housing Financing In Malaysia
}

Fathullah Asni \& Jasni Sulong

To Link this Article: http://dx.doi.org/10.6007/IJARBSS/v8-i12/5149

DOI: $10.6007 /$ IJARBSS/v8-i12/5149

Received: 28 Nov 2018, Revised: 19 Dec 2018, Accepted: 22 Dec 2018

Published Online: 30 Dec 2018

In-Text Citation: (Asni \& Sulong, 2018)

To Cite this Article: Asni, F., \& Sulong, J. (2018). Non-Ethical Elements in Tawarruq Munazzam Product for Islamic Housing Financing In Malaysia. International Journal of Academic Research in Business and Social Sciences, 8(12), 1013-1019.

Copyright: (C) 2018 The Author(s)

Published by Human Resource Management Academic Research Society (www.hrmars.com)

This article is published under the Creative Commons Attribution (CC BY 4.0) license. Anyone may reproduce, distribute, translate and create derivative works of this article (for both commercial and non-commercial purposes), subject to full attribution to the original publication and authors. The full terms of this license may be seen

at: http://creativecommons.org/licences/by/4.0/legalcode

Vol. 8, No. 12, 2018, Pg. 1013 - 1019

Full Terms \& Conditions of access and use can be found at http://hrmars.com/index.php/pages/detail/publication-ethics 


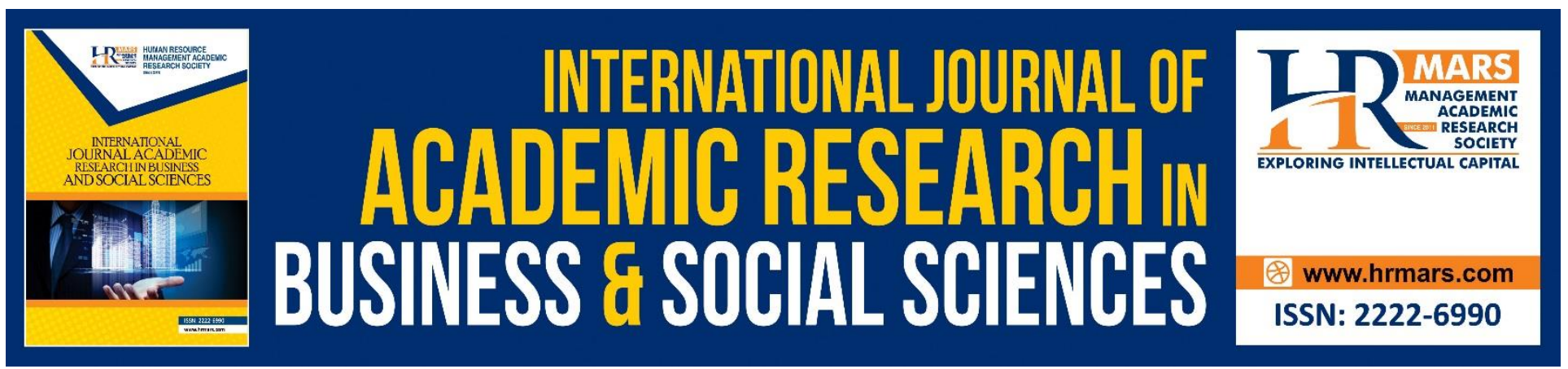

\title{
Non-Ethical Elements in Tawarruq Munazzam Product for Islamic Housing Financing In Malaysia
}

\section{ABSTRACT}

\author{
Fathullah Asni \& Jasni Sulong \\ School of Humanities, Universiti Sains Malaysia \\ Email: fathasni90@gmail.com, jasni@usm.my
}

This study is to identify non-ethical elements in tawarruq munazzam product as an identical bay' alinah and therefore to provide alternative methods in executing the deal. This study is qualitative in which data is collected through library research and interview method. The method of library research is to refer to the reference material derived from muamalat books, related bank circulars and journals. While the interview method is to interview the MBSB bank Shariah executive officer in an unstructured way. The findings show that there are four non-ethical elements in tawarruq munazzam contracts that include tyranny (zulm), treachery (ghubn), not trying to make sure sharia compliance in the product as well as the existence of illegal elements (hilah), ambiguity and obscurity (gharar). The findings also show that there is a temporary alternative method for tawarruq munazzam contracts to be applied.

Keywords: Non-ethical, Tawarruq Munazzam, Islamic Housing Financing, Malaysia, Legal

\section{INTRODUCTION}

Banking in Malaysia runs through two systems that are conventional and Islamic. This is in contrast to most Muslim countries in the Middle East for taking the approach of abolishing the conventional system and running a single Islamic banking system. Initially, the approach in implementing these two systems is because they want to promote competitive Islamic banking and to develop aggressively in conjunction with conventional banking as new in the market compared to conventional banking (Haron, 2005). Above those factors, today, Islamic banking is very advanced and competitive because it has received high demand among the public until it becomes highly competitive. This is consistent with current data showing that global Islamic banking assets worth USD 1.88 trillion (RM8.08 trillion) by the end of 2015 and Malaysia is among the major contributors to the figure (IFSB, 2016).

Despite many positive news that is hovering in the development of Islamic banking, however in midst of the growth, it was mixed with a range of controversies, especially on the product structure. It started with the offer of bay' 'inah product which was criticized by the majority of current Middle Eastern scholars as well as traditional muamalat scholars (Asni et. al., 2018a). After gaining spiky 
INTERNATIONAL JOURNAL OF ACADEMIC RESEARCH IN BUSINESS AND SOCIAL SCIENCES Vol. 8, No. 12, Dec, 2018, E-ISSN: 2222-6990 @ 2018 HRMARS

criticism of the product, Islamic banks in Malaysia shifted to tawarruq munazzam-based products that substituted the former (Asni et. al., 2018a). But once again it gets immense criticism by the majority of Middle Eastern scholars (Ahmad et. al., 2017). This criticism is inevitable while using the Islamic brand that either individual or institution is obligated to follow Islamic ethics as well as to make a priority in fulfilling the shariah goal. According to al-Husni (2014), the ethics that must be observed in the Islamic finance are avoiding from all forbidden elements such as tyranny (zulm), dishonesty, untrustworthy, illicit, uncertainty (gharar) and ambiguity (shubhat). Every transaction should be put in clear explanations either on products as well as in contracts. All of the ethics are derived from primary sources that are the Quran and the Sunna.

Besides, referring to the Islamic Financial Services Act 2013 (Act 759) which is the latest Act regulating the Islamic financial business sector in Malaysia. Among the issues highlighted in this Act is that every business activity undertaken by the bank must meet the requirements of the Islamic law. Therefore, this study is to examine elements that are not in line with Islamic ethics in widely used tawarruq munazzam products as well as suggest alternative methods.

\section{NON-ETHICAL ELEMENTS IN TAWARRUQ MUNAZZAM PRODUCT}

Figure 1: Modus Operandi Tawarruq Munazzam at Bank Islam

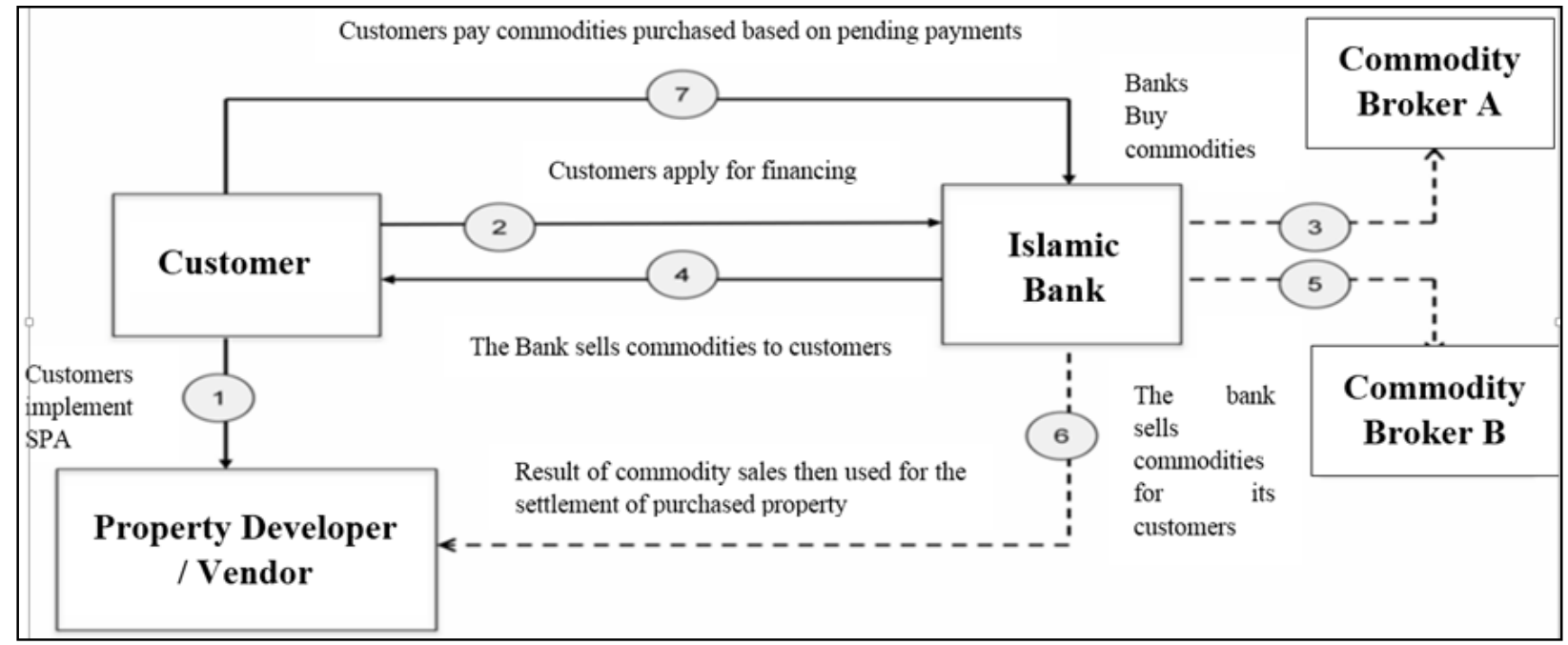

Source: The Bank Islam (M) Berhad.

Based on Asni's findings (2018c), 15 banks are offering Islamic housing financing products in Malaysia and only 10 of them provide tawarruq munazzam products for financing. This shows that the products of tawarruq munazzam have dominating compared to other products in the market such as ijarah muntahiah bi tamlik, ijarah mausufah fi zimmah, tawarruq, bai bithaman ajil and musharakah mutanaqisah.

However, the type of tawarruq munazzam that has been offered got overwhelm criticized by the majority of current scholars. The essential point goes to a business plan that agreed simply to justify loan, which is untie to riba (usury). It is different from tawarruq fardi which is naturally occurring between buyers and sellers in open markets (Ahmad et. al., 2017). For more details, there are three elements on tawarruq munazzam that has been criticized, that is, firstly; commodity sale and 
purchase are not intended and desired by the contracting parties, but what they want is only money (Ajija, 2009). All other transactions that are done only to justify getting the funds.

Secondly, a third party that exists in the tawarruq munazzam's transaction is merely a trick to make the contract permissible (halal) by having a buying and selling transaction in the commodities exchange. In other words, the third party is only a ploy to prevent such transactions barely took place between sellers and buyers, which is forbidden by the shariah, therefore it involves others as a third party as well. Consequently, the item does not return to the seller but is transferred to another person. Basically, Islamic scholars allow tawarruq by having a third party in the contract aiming to prevent from observing riba (usury) by both parties. However, the aim is at halt in the current tawarruq practice when the third party have been designed. They have promised to buy the commodity that sold by bank. At this point, this is differed in actual tawarruq where the third party are outsider and do not know about the first transaction that has been run (Ab Rahman, et. al., 2010). Therefore, the designed transaction was known by tawaruq munazzam and have been criticized by majority of the jurists.

Thirdly, a clear tricks took place when the bank at the same time is appointed as agent for selling. At this point, the deal involves an initial agreement between the bank and the last buyer guaranteeing that the latter will buy whatever the former offers at the same purchasing price. While in the tawarruq fardi is vice-versa where the customer who sells commodities. This is because basically tawarruq is an independent contract whereby every individual involved in the transaction will do any transaction without intervention. But in tawarruq munazzam contract that is practiced by banks at the present time, there is a wakalah contract where the bank is appointed as a representative to sell commodities ensuring the bank receives a fixed return from the instrument. The existence of wakalah in the contract is a trick, whereas those who carry out tawarruq transactions does not require wakalah contract, but it is added to achieve cost-effectiveness and smoothening of money liquidity (Ajija, 2009). According to Mahyudin (2015), the concept applied in tawarruq transactions by Islamic financial institutions in Malaysia that the bank represents customers in selling assets to a third party who in reality are also the same bank. The activity is becoming a contract of selling products to oneself and this will lead to the issue of bay' wakil linafsihi. Based on the AAOIFI syariah standard (2015), the representative is not allowed to sell the goods he bought for himself and the representative is not allowed to contract with himself as it is named bay' wakil linafsihi.

Besides being involved with prohibited trick issues, tawarruq munazzam is very likened to bay' 'inah contract which is prohibited by the majority of Islamic scholars as having a trick of riba on it deferred sale (Yusof, 2016; Asni et. al., 2018b). Thus, tawarruq munazzam has a problem with the ethical aspects of Islamic finance because when buying the asset on credit, the buyer does not intend to use or utilize it, but just want to sell it to get cash. Accordingly, there is a deceitful element (fraud) as well as syubhat (ambiguity) when bank claims tawarruq munazzam scheme is sharia-compliant but involve with plan to get cash back. Moreover, banks are difficult to point out commodities purchased by the customers except by numbers. Therefore, in this case, Sa'id ibn a-Musayyib prohibited the seller engages in the second transaction of sale, while Hanafi jurist categorized it under bay' al-inah for having similar purpose in getting money (Mahyudin, 2015). 
INTERNATIONAL JOURNAL OF ACADEMIC RESEARCH IN BUSINESS AND SOCIAL SCIENCES

Vol. 8, No. 12, Dec, 2018, E-ISSN: 2222-6990 @ 2018 HRMARS

\section{TEMPORARY ALTERNATIVE FOR TAWARRUQ MUNAZZAM CONTRACTS}

Based on the above discussion, it is very clear grounds and disparity between tawarruq munazzam and tawarruq fardi which led to be criticized by the majority of Islamic Scholars. Despite of having prohibited tricks, it also involves bay 'inah and riba. Hence, the researcher wants to propose a temporary alternative to tawarruq contracts that are more in line with Islamic law. It is temporary because the bank is a large entity to change its system drastically, but requires a gradual change. The modus operandi of proposed tawarruq which is according to syariah is;

Figure 2: Temporary Alternate Tawarruq

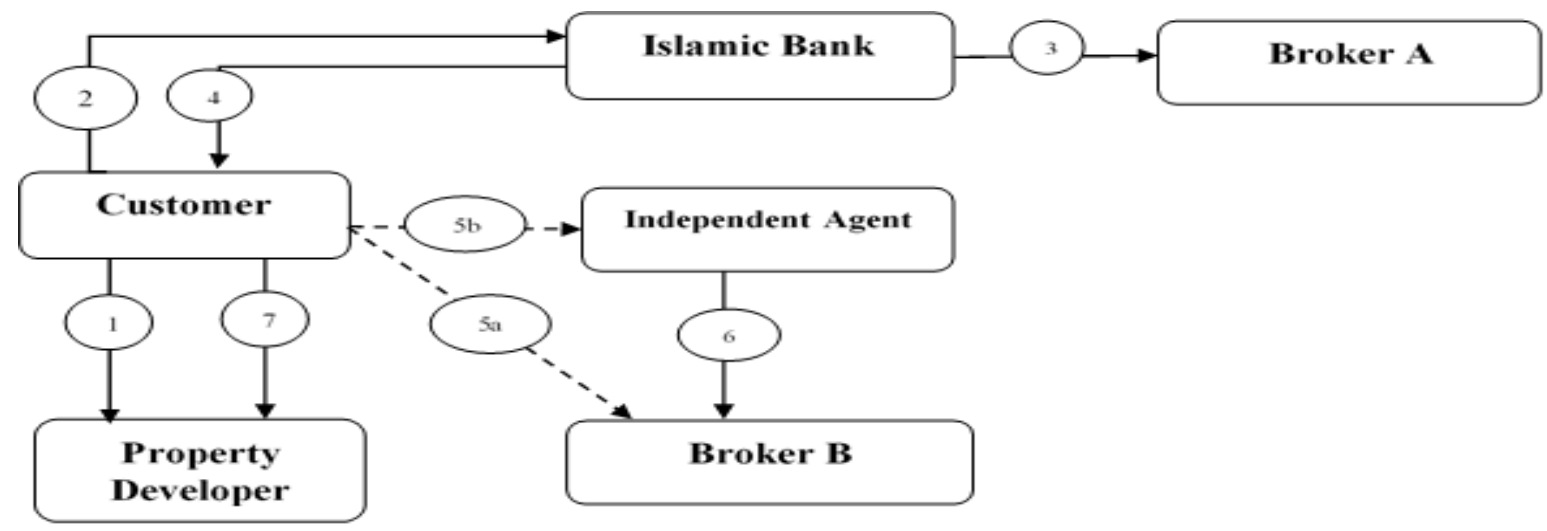

Source: This research

1) A customer signing a Sale and Purchase Agreement with developer for purchasing a house.

2) The customer executes tawarruq process where it will apply to the bank to purchase commodities in installments. However, according to AAOIFI (2015), the deal only permitted with condition that the client is in need to get the money and there is no other way to get financing to buy the first home. The Bank will issue letter of undertaking which involves wa'd mulzim that customer agrees to purchase commodity from the Bank. Wa'd in contract is required by Majma' al-Fiqh al-Islami (2018).

3) The Bank will purchase a commodity from Broker A for a cash price, received the commodity and own it perfectly. This is because to avoid banks selling the commodity that does not belong to them.

4) The Bank sells and delivers the commodity purchased to the customer using murabahah transaction, involving cost price and profit (Majma' al-Fiqh al-Islami, 2018). Then the customer buys by instalments using bay' taqsid contract. According to the Majma' al-Fiqh al-Islami (2018), bay' taqsid is required with particular terms and during purchasing arrangement, the customer should witness the commodity to avoid gharar.

5) The customer sells commodity purchased from the bank to Broker B in cash either on its own or appoint an external agent using a wakalah contract. Majma' al-Fiqh al-Islami (2018) requires wakalah in a deal that runs by representative.

6) Cash that earned by the customer will be paid to the developer to settle the remaining balance. 


\section{REDUCTION OF TAWARRUQ CONTRACT IN BANKING}

According to Abd Sattar Abu Ghuddah, banks should use tawarruq contracts within $15 \%$ to $20 \%$ range, i.e. financing aimed at obtaining money-liquidity such as personal financing (Murtadha, 2018). Reducing the use of tawarruq munazzam contract is important because it has been criticized by the majority of Shariah scholars about its shariah compliance status. It is also a suggestion from AAOIFI (2015) to circumvent the deal. Hence for housing financing, it is recommended that banks revolve and use products that are visibly following Islamic principles, i.e. ijarah and musyarakah. These contracts are listed in the shariah resolution of the Bank Negara Malaysia which is facilitating banks to adopt them.

\section{CONCLUSION}

Majority of the current Islamic scholars have decided that tawarruq munazzam contract is unlawful because it has some unethical elements of oppression, treachery, do not ensure sharia compliance, ambiguity and obscurity. The above discussion portrays that these elements exist in the contract and therefore it is contrary to the shariah as well as contradict to provision of the Islamic Financial Services Act 2013 (Act 759). However, there is an alternative proposed for applying the product by eliminating unethical elements, where the transaction process should be made in natural without any ploy or design. Otherwise, there are other more compliant products such as ijarah and musyarakah mutanaqisah which have been approved by Bank Negara Malaysia.

\section{Corresponding Author}

Fathullah Asni

School of Humanities, Universiti Sains Malaysia, 11800 Pulau Pinang, Malaysia

Email: fathasni90@gmail.com

\section{ACKNOWLEDGEMENT}

The research is funded by the Fundamental Research Grant Scheme (FRGS) by the Higher Education Ministry of Malaysia, Phase 1/2017, No. 203/PHUMANITI/6711589.

\section{References}

AAOIFI. (2015). Shariah Standard. Bahrain: AAOIFI.

Ab Rahman, A., Mohammad, S., \& Salleh, I. M. (2010). BAY'AL-TAWARRUQ DAN APLIKASINYA DALAM PEMBIAYAAN PERIBADI DI BANK ISLAM MALAYSIA BERHAD. Jurnal Syariah, 18(2).

Ahmad, E. F., Shihama, M., Tarmizi, M., Ashikin, N., Jibril, S. M., Djama, S. I., \& Muneeza, A. (2017). Tawarruq as a Product for Financing within the Islamic Banking System: A Case Study of Malaysian Islamic Banking System. International journal of management and applied research, 4(1), 31-43.

Ajija, S. R., Fathia, M., \& Suarni, A. (2010). Tawarruq: Issue \& Challenge. Kuala Lumpur: IIUM.

al-Husni, A. Y. (2014). al-ljtihad fi al-Mu'amalat al-Maliyyah al-Mu'asirah. Master Thesis, Fakulti Syariah dan Undang-Undang, Kolej Universiti Insaniah, Kedah 
INTERNATIONAL JOURNAL OF ACADEMIC RESEARCH IN BUSINESS AND SOCIAL SCIENCES

Vol. 8, No. 12, Dec, 2018, E-ISSN: 2222-6990 C 2018 HRMARS

Asni, F. A. H. M., \& Sulong, J. (2018a). The Model of Istinbat by the Shariah Advisory Council ofCentral Bank of Malaysia. International Journal of Academic Research in Business and Social Sciences, $8(1), 12-23$.

Asni, F., \& Sulong, J. (2018b). Hybrid Contracts according to Islamic Perspective. International Journal of Academic Research in Business and Social Sciences, 8(5), 453-458.

Asni, F., \& Sulong, J. (2018c). Syariah Analysis on Hybrid Contracts and Its Applications in Islamic Housing Financing in Malaysia. Prosiding paper at Persidangan Pasca Siswazah Pengajian Islam 2018 on $16 / 3 / 2018$.

Haron, S. (2005). Sistem Kewangan Dan Perbankan Islam. Kuala Lumpur: Kuala Lumpur Business School Sdn Bhd.

IFSB. (2016). Islamic Financial Services Industry Stability Report. Kuala Lumpur: Islamic Financial Services Board

Mahyudin, M. I. (2015). Aplikasi Tawarruq Dalam Sistem Perbankan Islam: Kajian Di Bank Muamalat Malaysia Berhad. Master dissertation. Department of Shariah and Economics. Academy of Islamic Studies, Universiti Malaya.

Majma' al-Fiqh al-Islami. (2018). Majma' al-Fiqh al-Islami. (Accesed at http://www.iifa-aifi.org/ on $31 / 7 / 2018$ )

Murtadha, F. interview with MBSB Bank Shariah Officer at Wisma MBSB Kuala Lumpur on 31/7/2018

Yusoff, A. F., ZAIN, M. N. M., YAACOB, S. E., Hanafi, H., Abdul Ghani, N. A. R. N., Idrus, A. M. M., \& Radzi, M. S. R. M. (2016). Islamic Personal Financing Instruments in the Malaysian Banking Industries: Issues and Alternatives. Journal of Contemporary Islamic Law, 1(1), 24-38. 